\title{
Review Article \\ Ecological and Edaphic Drivers of Yam Production in West Africa
}

\author{
Dora Neina $(\mathbb{D}$ \\ Department of Soil Science, School of Agriculture, University of Ghana, P.O. Box LG 245, Accra, Ghana \\ Correspondence should be addressed to Dora Neina; dneina@gmail.com
}

Received 6 April 2021; Accepted 29 May 2021; Published 4 June 2021

Academic Editor: pankaj bahatt

Copyright ( 12021 Dora Neina. This is an open access article distributed under the Creative Commons Attribution License, which permits unrestricted use, distribution, and reproduction in any medium, provided the original work is properly cited.

\begin{abstract}
Yam is an important food and cash crop in West Africa (the yam belt) whose production is traditionally nonsedentary due to its substantial nutrient demand. Population growth, urbanization, and existing soil degradation have made nonsedentary farming virtually impossible. Despite the numerous research invested in yam production within and outside the yam belt, some gaps remain to be filled owing to changing climate events and global developments. Alarmingly, the yam belt is facing sharp yield declines despite increasing production areas. The key edaphic and ecological drivers of yam production in the global yam belt were reviewed. The implications for yam production were discussed along with prospects for future research, sustainable production, and soil management. The main findings are that (1) agroecological zone, postplanting cultural practices, and climate change and variability ecological drivers, while (2) tillage, soil type, texture, and fertility were the edaphic factors. The most critical among the drivers, principally, soil fertility, entails the biological and chemical through which nutrients are released lude, and physical soil fertility which enhances low bulk density, porosity, and water retention for free yam tuber expansion. Soil fertility was the most cited driver, which explains why yam is often the first crop in the cropland cultivation cycle in the yam belt. Data show that yam yields decline with time under native fertility and mineral fertilizer application due to the voracious nutrient extraction by tubers. Conversely, yields increase chronologically under organic fertilizer application due to the additive effects of the latter on soil properties. Thus, a yam fertilizer program to develop specific yam fertilizer formulations and the adoption of the Terra Preta Model are proposed to sustain future yam production.
\end{abstract}

\section{Introduction}

Yam (Dioscorea spp.) is an important food and cash crop grown mostly in West Africa. Globally, this zone of yam production is called the "yam belt" [1]. It accounts for about $98 \%$ of the global yam supply [2], particularly from the top four countries including Benin, Côte d'Ivoire, Ghana, and Nigeria [3]. In 2019, Nigeria was the top producer accounting for $73 \%$ of yams produced in West Africa followed by Ghana (12.1\%), Côte d'Ivoire (10.5\%), and Benin (4.5\%) among the top four producers [2]. Yam is a food security and income generation crop because it can be stored, traded, and consumed during the dry, off-season or "hungry months" when the production of other crops is impossible. Consequently, yam is considered a West African cash crop [4] and a source of livelihood for millions of people involved in its production through distribution at the local, regional, and global scales. Within the yam belt, over 60 million people are directly and indirectly in involved yam production [3]. Yam is, therefore, economically important part of the GDP of the top producers and exporters. For instance, Ghana's yam exports between 2017 and 2018 increased by USD 5.4 million [5].

Globally, yam production increased significantly from 1990 to 2019 owing to population growth and global demand for the crop. According to FAO estimates [2], yam production (in tons) within the period has increased by almost threefold. With a total land area of about 1.5 million $\mathrm{km}^{2}$, the population of the top four producers stands at about 284 million [6]. However, the area under yam cultivation increased by fourfold within the same period, whereas the average annual yield fluctuated ranging from 8 to $12 \mathrm{tha}^{-1}$ with an observed decline by about $2 t \mathrm{ha}^{-1}$ in the last nine years [2]. With the rising populations, production, and demand for yam amidst the global climate change crisis, it is imperative to identify the critical drivers of yam production and adapt, where possible, for increased food security and 
improved livelihoods of the large number of smallholder farmers involved in its production.

Yam cultivation is unique in the sense that it follows a nonsedentary pattern of traditional "shifting cultivation," bush fallowing, and land rotation. Thus, the availability of suitable land has become a nerve-racking challenge [7] amidst the high population growth. The yam cropping system often requires freshly cleared land (Figure 1), either virgin or fallowed, which is mostly ploughed before yam mounds or ridges are prepared for planting. After the first cropping season, yam yields often decline rapidly because yam has a substantial demand for soil organic matter (SOM), nitrogen $(\mathrm{N})$, potassium $(\mathrm{K})$, and phosphorus $(\mathrm{P})$ to achieve consistently acceptable yields. The aftermath is a scarcity of fertile land and soil degradation as the heavy feeder voraciously extracts a substantial amount of nutrients from the soil of newly cleared land in a cropland expansion style. This makes it difficult for smallholder yam farmers, who constitute the majority at the production level, to change the yam cropping system to a sedentary system. The challenge is further aggravated by the labor-intensive nature of yam production, particularly tillage and weed control $[7,8]$ which account for about $40 \%$ of the total cost of production [7, 9]. Sadly, there is a shortage of agricultural labor in the yam belt due to the declining involvement of youth in agriculture and rural-urban migration. Consequently, high labor costs have been widely reported in yam production [10], placing limitations on farmers' ability to establish large yam farm sizes [11]. Thus, many farmers have resorted to the intensive use of synthetic herbicides $[12,13]$ such as glyphosate for pre- and postplanting weed control [13]. The continuous and persistent use of herbicides could also introduce the residues of active ingredients in yam tubers through uptake $[13,14]$.

Research on yam production within and outside the yam belt has received so much attention in the past. However, there remain some gaps to be filled owing to increasing populations, land scarcity and short fallows, changing trends in climate events, and global development. The aim of this review is to identify the key edaphic (soil) and ecological drivers of yam production in the global yam belt, discuss their implications for future yam production, and present future research prospects for sustainable yam production and soil management. The expected results of this review may be useful for the adaptation of yam production in different soil types and ecological zones to enhance yields and sustain yam production amidst increasing population and land scarcity.

\section{Ecological Drivers}

2.1. Agroecology. Yam tuber yields are controlled by interactions of several physiological and environmental factors [1]. External environmental factors such as warm weather conditions, the duration of sunlight or photosynthetic active radiation, humidity, rainfall amount, and distribution limit yam production to specific hotspots within the yam belt. These all have implications for the existence of constraints such as environmental stresses and incidence of pests and diseases [11]. The most important product of the yam plant

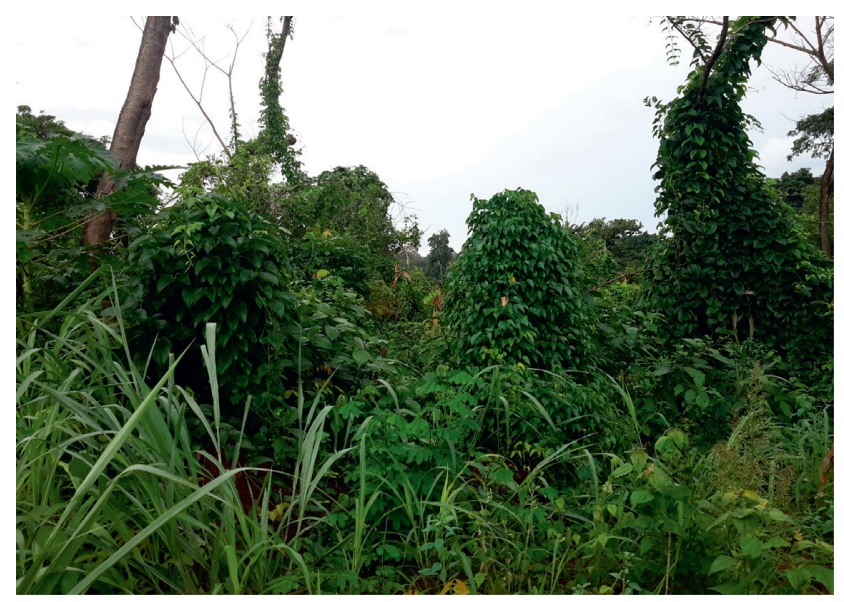

FIGURE 1: A yam farm established on a freshly cleared tertiary forest at Adansam in the Forest-Savannah Transition zone of Ghana. Many of the native shrubs were left to serve as stakes (photo credit: Dora Neina).

is an underground stem modification known as tubers containing food reserves [15]. The onset and degree of tuber formation are influenced by several environmental factors such as photoperiod or day length, temperature, light (intensity and quality), mineral nutrition, water availability, hormones, and gibberellins $[15,16]$. The environmental factors regulate the level of photosynthates available for storage in the tubers through their effect on the intensity and duration of photosynthesis and respiration [16]. These factors are required for proper physiological balance to enhance proper biochemical processes in the plant. Generally, yam requires less humid but more open canopy environments and habitats with maximum solar radiation for photosynthesis [1, 17].

Yam cultivation is suited to the humid and subhumid lowlands. In the yam belt, the most suitable agroecological zones for yam production (also called yam agroecology) are Deciduous Forest and Savannahs [3]. In Nigeria where most of the world yams are produced, the major production hotspot is the Derived Savannah and Southern Guinea Savannah zones $[18,19]$. In Ghana, the major producing zones are Guinea Savannah and the Forest-Savannah Transition zones [20, 21]. In Côte d'Ivoire, yam is dominantly produced in the northeast part of the Tropical Moist Deciduous Forest and the northeast extreme of the Tropical Rain Forest [22]. In Benin, most of the production is done in the Guinea-Sudan zone $[23,24]$ and within the tropical moist deciduous forest as described by the FAO [22]. It is estimated that about $70 \%$ of yam production in Nigeria and Ghana occurs in the Derived Savannah, 20\% in the Forest zone, and $10 \%$ in the southern Guinea Savannah [12]. In these hotspots, yam requires well-distributed rainfall with an annual average range from 900 to $2000 \mathrm{~mm}$ (Table 1). Additionally, during the period of maximum growth occurring between 14 and 20 weeks after planting, temperature ranges between 20 and $35^{\circ} \mathrm{C}$ are essential [1] (Table 1) for tuber bulking (Figure 2) [31]. In an experiment and a modeling study of water yam where the development cycle 
TABLe 1: Common ecological conditions for yam production in West Africa.

\begin{tabular}{lccc}
\hline Agroecological zone & Rainfall $(\mathrm{mm})$ & Temperature $\left({ }^{\circ} \mathrm{C}\right)$ & Reference \\
\hline Forest-Savannah transition & $1000-1500$ & $18-35$ & (Udoh et al. 2000; $[20,21,25,26]$; Cornet et al. 2014; Akanji et al. 2018) \\
Guinea Savannah & $1000-1401$ & $24-33$ & {$[27,28]$} \\
Humid Forest/Forest & $1300-2000$ & $21-32$ & (Udoh et al. 2000; [20, 21, 26, 29] \\
Forest-Coastal Savannah & $1050-1200$ & $21-34$ & {$[21]$} \\
Guinea-Sudan transition & $1100-1200$ & $22-32.8$ & {$[24,30]$} \\
Derived Savannah & $900-1200$ & - & (Udoh et al. 2000; [26] \\
\hline
\end{tabular}
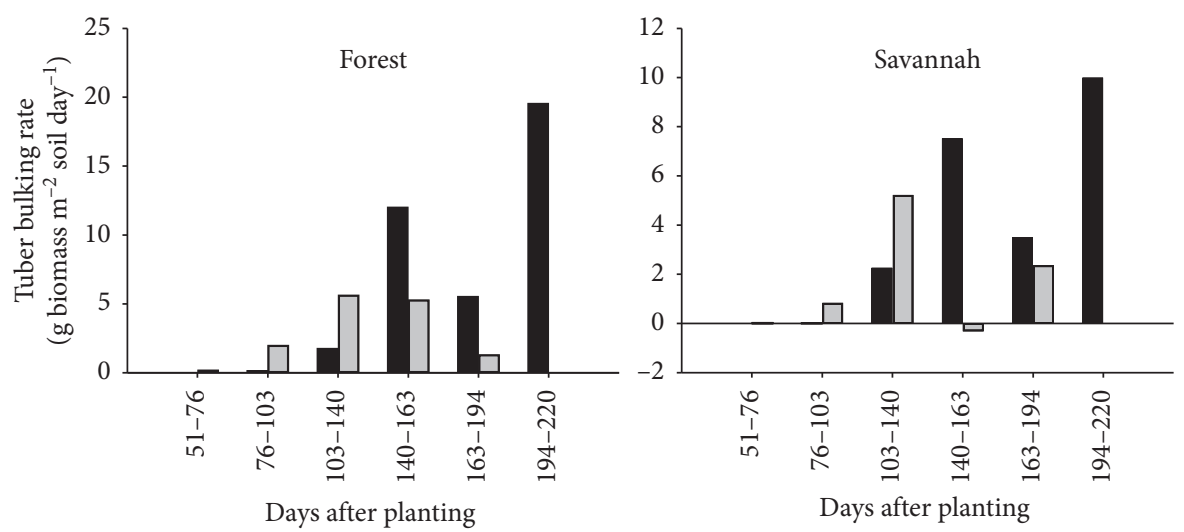

FIGURE 2: Impact of ecological zone on the tuber bulking rate of D. alata (black bar) and D. rotundata (gray bar) applied fertilizers (urea, triple super phosphate, potassium sulphate, and magnesium sulphate) in forest and savanna sites in Central Côte d'Ivoire in 2003. D. rotundata was harvested at 194 days after planting. No statistical significance was included in the original data (source: adapted from Diby et al. [31]).

was split into "emergence-tuber initiation" and "tuber initiation-harvest." Marcos et al. [32] observed that the duration of "Emergence-Tuber initiation" was more affected by the environmental factors than that of "Tuber initiationHarvest." More specifically, they found a greater effect of photoperiod than temperature on "Emergence-Tuber initiation." This was accompanied by a higher variation in the combined effects of these environmental factors.

Yam has a long growing period ranging from 6 to 12 months depending on species, climatic conditions [31,33], planting material (seed tubers or sections of tuber), genotype, location, the effective duration of growth, and the agroecological zone [7]. This is further influenced by the season and planting dates in each agroecological zone [3]. In the yam belt, agroecology determines the different yam species grown as well as their yields. For instance, in Côte d'Ivoire, D. alata (water yam) is predominantly produced in forest or savannah woodlands, while $D$. rotundata (white guinea yam) prevails in savannah areas [11]. In Benin, the Guinea-Sudan zone has a large gene-pool of yam varieties [30].

2.2. Cultural Practices. The two most important postplanting cultural practices employed in traditional yam production are mulching (capping) and staking. These modify the external yam plant environmental conditions by creating a microclimate for the intended benefits. Mulching is a modification of the soil microclimatic on the mound summit soon after planting yam setts. It involves the placement of dried grass or leaves on the mound overlaid with mud, soil clods, or stones to keep it in place so that it is not blown away by the wind [1]. Mulching is so critical that drastic yield reduction can occur if it is not done [1]. Therefore, it is indispensable in certain areas $[34,35]$. Its benefits include increased soil moisture and reduction of soil temperature in the mound $[1,36]$. Aside from the fundamental benefits of mulching, the mulches also improve yam tuber yields by releasing plant nutrients into the soil $[35,37]$ depending on the material used. For instance, Chromolaena odorata (L.) R. M. King \& H. Rob. and Tithonia diversifolia (Hemsl.) A. Gray mulch used at 5.0, 7.5, 10.0, and $12.5 \mathrm{tha}^{-1}$ increased tuber yields by between 12 and $82 \%$ with Tithonia diversifolia having a greater effect on yields than Chromolaena odorata [37].

Staking is the most popular cultural practice employed in traditional yam production. It is important for the yam vine because the stakes are used to support the light-loving vines to orient them upright, exposing the leaves to the sun to benefit from maximum sunlight [1]. Staking can be optional where there are labor shortages, limited availability of staking materials [38], and for yam species whose yield is less dependent staking [7]. The stakes used are mostly obtained from bamboo, native trees, twines, ropes, wood, and so on. The types of stakes commonly used are the vertical and trellis staking $[20,38]$. The effect of staking on yield tends to vary with yam species. For instance, while $D$. alata can adapt to nonstaking conditions, $D$. rotundata does not, although some of the $D$. rotundata cultivars can thrive without staking $[20,39]$. Earlier reports from the IITA (2009) cited by Verter et al. [40] and Cook et al. [41] suggest that staking does not 
only improve photosynthesis but also prevent leaf diseases, allow for intercropping, and increase the yields of D. rotundata by up to $105 \%$. This effect is found to be influenced by the cultivar [7] and the ecological zone [20]. In more sunny environments, trellis staking produced the highest benefit-cost ratio in Ejura of the Forest-Savannah Transition zone than in Fumesua of the Humid Forest zone [20]. This suggests that staking may be more beneficial in rather sunny environments. Despite all of these benefits, the labor cost for staking in yam is a major discouragement as it accounts for $20 \%$ of all work in yam production [39].

2.3. Climate Change and Variability. Yam cultivation in West Africa is purely rain-fed and is mostly carried out in the major rainy season for up to nine months. This implies that the rainfall distribution and temperature patterns should conform to the physiological processes of the yam plant to produce good yields. Sadly, the climate picture over the region gives a bleak future, where the climate and its impacts will be more unstable than ever [42]. It is already observed that the rainfall amount has risen in the past decade [43]. Climate change models predict a future temperature rise of about 1.5 to $6.5^{\circ} \mathrm{C}$ in West Africa with increases/ reductions in rainfall by $30 \%$ compared to the reference period 1976-2005 [44]. These all have implications for yam production owing to its long growing period. It is also predicted that with a fairly stable rainfall regime, the projected temperature rise might still have a daunting effect on crop yields owing to high evapotranspiration and water stress [45]. The projected trend in climate variables has resulted in droughts, heavy rains, flooding, or increased temperatures which aggravate the already existing agricultural production constraints of water availability and soil quality in the yam belt [46]. Currently, seasons have either been shifted or shortened. Interestingly, the majority of farmers are aware of climate change and its impact and have observed this over the years [34]. About $98 \%$ of farmers surveyed in southern Nigeria reported that they observed delayed onset of rains for the season and $69 \%$ observed excess rainfall, while $66 \%$ experienced increased temperature regimes. These, according to the farmers have resulted in yam yield decline [34]. With the aid of the REMO regional climate model, it was predicted that climate change will cause a decline in yam yields in the Savannah zone of West Africa between 2021 and 2050 [47]. Climate change interacted with soil conditions where ferruginous soils (soil enriched with iron oxides) without concretions showed $48 \%$ yield decline, $36 \%$ for ferralitic soils (iron and aluminum rich) and normal mineral soils 33\% compared to baseline (1961-2000) yields in the SRES A1B Emissions Scenario [47]. This calls for future adaptations to yam production as drastic yield declines are expected.

\section{Edaphic Drivers}

3.1. Tillage. The state of physical soil properties hugely affects yam yields, which accounts for the demand for organic matter-rich soils and appropriate tillage practices (i.e., mounding, trenches, and ridging) used in the production. Traditionally, yam has been grown on ridges and mounds over the years because the tubers require low soil bulk density for bulking. This is attributed to the nature of yam bulking in soil. Ennin et al.[21] and Lebot [1] explained that the tubers of yam expand as they penetrate the soil compared to cassava which penetrates the soil before expanding. In tilled and untilled soils, Agbede [48] observed that soil bulk density had a more pronounced effect on yam yield than chemical properties of soil. Specifically, when the bulk density decreased from 1.5 to $1.3 \mathrm{~g} \mathrm{~cm}^{-3}$, yam yields increased by $38 \%$, while the mean tuber weight was found to increase by $35 \%$ as a result of the effect of low soil bulk density [48]. In Nigeria, yam is reportedly grown on flat and untilled land under zero tillage, manual clearing, trenches filled with fertile soil, mounds of different sizes (small and large) and ridges, and so on. [48, 49]. In some cases, trenches of about $30 \mathrm{~cm} \times 30 \mathrm{~cm} \times 30 \mathrm{~cm}$ are used depending on the soil type, soil depth, microclimate, and topography [48]. Although research has confirmed that tillage influences yam yields, mound size was found to have a more pronounced effect on tuber yield than fertilizer application [49]. This depends on yam species. For instance, when mound size increased from small to large, $D$. rotundata yields increased by 1.3 to 1.5 times, while $D$. alata increased by 1.2 to 1.4 times [1] citing Dumont et al. (2006). Yam mounds and ridges produced superior effects on both tuber length and weight compared to zero tillage and manual land clearing. Among the tillage practices conducted on a Luvisol (i.e., zero tillage; manual ridging; manual mounding; ploughing + harrowing; ploughing + harrowing + ridging), Agbede and Adekiya [50] found higher tuber yields under ploughing + harrowing + ridging three consecutive years. This increased with time through the period and was closely followed by manual mounding, manual ridging, and so on. The effects of mounds and ridges on yam yields appeared to be mixed. For instance, Odjugo [36] found 36\% higher tuber yields in mound tillage compared to ridge tillage, whereas Ennin et al. [21] found no differences in yam yields from mounds and ridges except for tuber shape. This difference could be attributed to the species effect since the results of Odjugo [36] was obtained from $D$. cayenensis cultivated at one site and in two seasons, whereas those of Ennin et al. [21] were obtained from two $D$. rotundata varieties (Dente and Pona) at four different sites and soils. The size of ridges commonly used ranged from 40 to $45 \mathrm{~cm}$ height [20], whereas mound height ranges from 20 to $75 \mathrm{~cm}$ high $[27,31,49,51]$ and $1 \mathrm{~m}$ wide at the base $[27,52]$. Research and farm surveys show that ridging appears to have certain advantages over mounding. For instance, ridging could reduce the cost of mounding by $50 \%$ and can also increase the planting density (MEDA 2011). It is estimated that ridges produce a planting density of 10,000 to 20,000 plants $\mathrm{ha}^{-1}$ [1], MEDA 2011, [53] compared to 5,000 to $6,000 \mathrm{ha}^{-1}$ of farmer's mounding practice (MEDA 2011). Another benefit of ridging is that it reduces labor requirements and may promote sedentary yam farming practices (MEDA 2011). Despite these benefits, some farmers in Ghana stick to mounds because poor yam yields were obtained from 
mechanized ridges that were introduced into the ForestSavannah Transition zone of Ghana in the 1960s [54]. Ridges are effective for land space management in yam production. They were applied as an improved agronomic practice together with the treatment of seed yam using insecticide and fungicide, trellis staking, and NPK 45:45:60 fertilizer application to improve tuber yield in two yam farming locations in the Forest-Savannah Transition zone of Ghana [55]. At a spacing of $1.2 \mathrm{~m} \times 0.8 \mathrm{~m}$ between and within ridges and a plant population of 10,416 plants ha ${ }^{-1}$, tuber yield increases of 196 and 205\% were obtained from both locations compared to the traditional practice of mounding at $1.5 \mathrm{~m} \times 2 \mathrm{~m}$ with about 3400 plants $\mathrm{ha}^{-1}$, no fertilizer application, and vertical wood staking at 2 plants per stake. In a nontraditional aeroponic system involving the use of yam minitubers, Aighewi et al. [56] obtained 100,000 plants $\mathrm{ha}^{-1}$ with a spacing of $1 \mathrm{~m} \times 0.1 \mathrm{~m}$ between and within ridges. However, increased plant density from ridging may also have implications for yam tuber yields in some cases. This has been observed by Law-Ogbomo and Osaigbovo [57] who found increased tuber yields with plant density up to a critical point per unit area in three different field trials and recommended an optimum plant density of 10,000 plants $\mathrm{ha}^{-1}$.

3.2. Soil Texture and Soil Type. Yam requires low soil bulk density as well as soil textural classes that enhance low soil bulk. Specifically, yam requires sandy loam to sandy clay loam soils with deep profiles $[58,59]$. These textural classes are mostly prevalent in Alfisols, Ultisols, and Oxisols which are used for yam production in the yam belt (Table 2). Generally, yams prefer light, friable and well-drained soils rich in SOM [58].

\subsection{Soil Fertility}

3.3.1. Native Fertility. As a heavy feeder, yam extracts an enormous amount of nitrogen $(\mathrm{N})$, potassium $(\mathrm{K})$, and phosphorus (P) for tuber development. Virtually all research conducted so far has estimated that yam either requires the same amount of $\mathrm{N}$ as $\mathrm{K}$, one and a half times or twice more $\mathrm{K}$ than $\mathrm{N}$ (Tables 3 and 4) $[63,66]$. The soil $\mathrm{pH}$ requirement is between 6 and $7[58,59]$ although lower $\mathrm{pH}$ values have been found for many soils (Table 2) used for yam cultivation. Thus, yam is cultivated in a shifting cultivation-land rotation pattern which allows for improved SOM content. Unfortunately, the rising yam production trends coupled with increasing populations have either reduced or made fallow periods impossible [7]. Thus, most of the soils currently used for yam cultivation contain low SOM, N, and cation contents (Table 2). A geostatistical mapping of soil fertility conducted by Jemo et al. [67] in soil of north-central and southeast Nigeria revealed that about $70 \%$ of the land under yam cultivation contains very low $\mathrm{N}$ contents in the range of 0.01 to $1.0 \mathrm{~g} \mathrm{~kg}^{-1}$. The same trend has been observed in other studies (Table 2) and confirms that declining soil fertility is a major constraint to yam production $[3,7]$. For instance, Diby et al. [61] assessed the effect of soil fertility on the yields of two yam species in Forest and Savannah soils of Côte
d'Ivoire and concluded that soil properties strongly influenced yam yields.

Yam yields decline significantly starting from the first year of cultivation (Table 5). For instance, Agbede and Adekiya [52] observed decreased tuber yields in a Alfisol (Luvisol) from the second year of cultivation under native soil fertility. The observed yield trend suggests that the yield of white yam decreased by $10 \%$ in the second year, whereas that of yellow yam decreased by about $12 \%$. In another study on white yam in the same soil type in Nigeria, Agbede et al. [50] observed a 5\% decline in tuber yield in the second and third years of continuous cultivation. This was attributed to a reduction in SOM content as one year of growing D. rotundata already reduced the soil organic carbon content by $50 \%$ [60]. In a three-year study on the effect of natural soil fertility on yam yield in Côte d'Ivoire. Diby et al. [61] consistently found higher fresh tuber yield in forest soil than in the savannah soil in each season. Sadly, the soil type was not identified. An observation of the soil data revealed that the forest soil had over twice the $\mathrm{C}, \mathrm{N}$, basic cation, and cation exchange capacity (CEC) contents than the savannah soil. Although both soil types had sandy loam texture, the forest soil had about two times more clay than the savannah soil. Given the clay content of the forest soil, a SOM content of $2.5 \%$ in the top $10 \mathrm{~cm}$ could easily produce a friable soil with a very low bulk density that is suitable for yam tuber development.

It is obvious that yam cultivation impoverishes the soil and deprives it of its chemical fertility. In the past, farmers used natural fallow periods of at least five years to restore the natural soil fertility for yam cultivation. In most cases, the fallow is dominated by grasses such as Andropogon gayanus Kunth. [23], which hardly adds adequate nutrients to the soil. Unfortunately, because of land scarcity, the fallow period has been shortened in many areas and is inadequate to restore the required fertility for sustainable yam farming. Recently, "artificial fallow" systems have been introduced where "high-value" plants are grown. These include Chromolaena odorata and some legume cover crops which are effective at improving the nutrient status of soils to increase tuber yields [23, 53]. The Chromolaena odorata fallows established in the Savannah zone produced yam yields are similar to those of the Forest zone [68]. There has been an interdependence of tuber yields on fallow duration and fallow species where Centrosema pascuorum (DC) Benth. and Centrosema brasilianum (L.) Benth. produced about twice the yields obtained from Mucuna spp. after a two-year fallow [53]. Overall, artificial fallows are being used in some areas to restore the nutrient status of soils because the voracious habit of yam tends to degrade soil. For how long can this continue as land becomes scarce?

\subsection{Nonnative Soil Fertility}

3.4.1. Mineral Fertilizers. In the past decades, mineral fertilizers were not a preferred nutrient source for yam production because farmers often depended on the natural soil fertility of newly cleared forest and fallowed lands. Mineral 
TABLE 2: Common soil properties of soils used for yam production in the yam belt.

\begin{tabular}{|c|c|c|c|c|c|}
\hline Soil type & Soil pH $\left(\mathrm{H}_{2} \mathrm{O}\right)$ & SOM (\%) & Total N (\%) & Cations* $\left(\mathrm{cmol} \mathrm{kg}^{-1}\right)$ & Reference \\
\hline Oxic Tropuldalf (Luvisol) & $5.4-5.9$ & $1.03,2.76$ & $0.10,0.19$ & $1.7-1.95$ & {$[27,37]$} \\
\hline Alfisol (Oxic Paleustalf) & 6.1 & 0.76 & 0.03 & 2.04 & [28] \\
\hline Oxic Kandiustalf & - & $1.63-2.17$ & $0.15-0.16$ & $3.59-3.93$ & (Akanji et al. 2018) \\
\hline Ultisols & $4.1-4.6$ & $1.04-2.11$ & $0.08-0.23$ & $0.42-0.71$ & {$[60]$} \\
\hline Ferralsols & $5.8-6.5$ & $0.93-2.5$ & $0.04-0.12$ & $2.03-6.29$ & {$[25,61]$} \\
\hline Ferric Acrisol and Ferric Lixisol & $4.6-5.2$ & $1.49,2.06,5.2$ & $0.11-0.13$ & 7.13 & {$[20,29,62]$} \\
\hline Plinthosols and Ferric Luvisols & $6.3-6.8$ & $0.93-2.30$ & $0.06-0.11$ & - & {$[24]$} \\
\hline Arenosols & 4.7 & $0.5-0.7$ & $0.05-0.06$ & $2.2-2.4$ & (Cornet et al. 2014) \\
\hline
\end{tabular}

${ }^{*}$ Without $\mathrm{Na}$; most published articles do not report soil types and $\mathrm{pH}$.

TABle 3: Average nutrients removed from the soil by D. alata, D. cayenensis, and D. rotundata tubers in western Nigeria and central Côte d'Ivoire applied with K fertilizer plus basal dressing of N and P and NPK fertilizer, respectively.

\begin{tabular}{|c|c|c|c|c|c|c|}
\hline \multirow{2}{*}{ Species } & \multirow{2}{*}{ Year } & \multicolumn{5}{|c|}{ Nutrient extracted $\left(\mathrm{kg} \mathrm{ha}^{-1}\right.$ dry matter) basis } \\
\hline & & $\mathrm{N}$ & $\mathrm{P}$ & $\mathrm{K}$ & $\mathrm{Ca}$ & $\mathrm{Mg}$ \\
\hline D. alata & 1976 & $65.3 \pm 4.1$ & $8.6 \pm 0.5$ & $82.4 \pm 5.2$ & $1.4 \pm 0.1$ & $4.1 \pm 0.3$ \\
\hline D. cayenensis & & $38.4 \pm 1.8$ & $5.4 \pm 0.3$ & $50.2 \pm 2.3$ & $1.1 \pm 0.1$ & $3.6 \pm 0.2$ \\
\hline D. rotundata, cv Efuru & & $44.9 \pm 2.7$ & $5.3 \pm 0.3$ & $50.9 \pm 3.0$ & $1.1 \pm 0.1$ & $3.1 \pm 0.2$ \\
\hline D. rotundata, cv Aro & & $40.0 \pm 2.1$ & $5.1 \pm 0.3$ & $44.2 \pm 2.3$ & $1.0 \pm 0.1$ & $3.2 \pm 0.3$ \\
\hline D. alata & 1975 & $47.5 \pm 4.1$ & $6.3 \pm 0.5$ & $59.9 \pm 5.1$ & $1.0 \pm 0.1$ & $3.0 \pm 0.3$ \\
\hline D. cayenensis & & $105.9 \pm 3.0$ & $14.8 \pm 4.2$ & $138.5 \pm 3.9$ & $2.9 \pm 0.1$ & $10.1 \pm 0.3$ \\
\hline D. rotundata, cv Efuru & & $110.4 \pm 11.8$ & $12.9 \pm 1.4$ & $125 \pm 13.4$ & $2.8 \pm 0.3$ & $7.6 \pm 0.8$ \\
\hline D. rotundata, $\mathrm{cv}$ Aro & & $82.4 \pm 7.9$ & $10.5 \pm 1.0$ & $91.0 \pm 8.8$ & $2.0 \pm 0.2$ & $6.9 \pm 0.6$ \\
\hline D. alata & 1974 & $128.3 \pm 7.1$ & $16.9 \pm 0.9$ & $161.7 \pm 8.9$ & $2.8 \pm 0.2$ & $7.9 \pm 0.4$ \\
\hline D. cayenensis & & $138.8 \pm 3.9$ & $19.4 \pm 0.5$ & $181.5 \pm 5.1$ & $3.8 \pm 0.1$ & $13.1 \pm 0.4$ \\
\hline D. rotundata, cv Efuru & & $155.3 \pm 5.9$ & $18.2 \pm 0.6$ & $176.1 \pm 6.2$ & $3.9 \pm 0.1$ & $10.7 \pm 0.4$ \\
\hline D. rotundata, $\mathrm{cv}$ Aro & & $140.3 \pm 3.4$ & $18.1 \pm 0.4$ & $154.9 \pm 3.8$ & $3.4 \pm 0.2$ & $11.2 \pm 0.3$ \\
\hline D. alata & 2003 & 216 & 10 & 178 & 27 & 14 \\
\hline D. rotundata & & 66 & 3 & 104 & 25 & 9 \\
\hline
\end{tabular}

Dataset for 1974-1976 ( $N=5 \pm$ SE, with no statistical significance) was adapted from Obigbesan and Agboola [63]. Dataset for 2003 was obtained from Diby et al. [64].

Table 4: Nutrients removed by $D$. rotundata tubers in a rice-yam rotation system under urea fertilizer application in Nigeria.

\begin{tabular}{|c|c|c|c|c|c|}
\hline Treatments & $\mathrm{N}$ & $\mathrm{P}$ & $\begin{array}{c}\mathrm{K} \\
\mathrm{g} \mathrm{kg}^{-1} \\
\end{array}$ & $\mathrm{Ca}$ & $\overline{\mathrm{Mg}}$ \\
\hline Control & $32 c$ & 17 & 59 & 0.7 & 1.2 \\
\hline Rice fertilization & $33 c$ & 19 & 60 & 0.7 & 1.2 \\
\hline Yam fertilization & $38 b$ & 17 & 51 & 0.6 & 1.3 \\
\hline Rice and yam fertilization & $41 \mathrm{a}$ & 18 & 51 & 0.6 & 1.2 \\
\hline
\end{tabular}

Data source: Kikuno et al. [65]. Letters in the first column indicates significant differences among the treatments at $5 \%$ level by Tukey test. The rest were not significant. No deviations were stated.

fertilizer usage has not gained grounds in many production areas. This is because of some reported detrimental effects of mineral fertilizers on yam quality, particularly poor taste, and textural properties and a hairy appearance which tend to repel many consumers although large tubers are obtained from the use of mineral fertilizers [54]. In Ghana, most farmers were reluctant to use mineral fertilizers for yam probably because of costs and availability [54], lack of suitable yam fertilizers (MEDA 2011), and inconsistencies of yam yield responses to fertilizer [69]. This might also be caused by differences in soil properties, ecological conditions, and yam species. In contrast, mineral fertilizer usage is more prevalent in many yam zones of Nigeria [70]. Some reports from Nigeria suggested that the use of mineral fertilizers caused the deterioration of tubers leading to short yam shelf life. However, Eze and Orkwor [70] are of the view that the observed effects of mineral fertilizers on yam tubers by previous researchers, might be caused by differences in species, varieties, and cultivars of yam since some cultivars of $D$. rotundata, for instance, are inherently prone to rotting with or without fertilizer application. Another probable reason for yam tuber quality deterioration following mineral fertilizer application could be the specific nutrient composition of fertilizers and the quality of soil used.

Fertilizer use became an option due to rapid soil fertility decline. With the advent of mineral fertilizer use, yam yield responses varied widely with site, time (first cultivation, second cultivation, etc.), yam species, ecological zone [25], soil type and fertility status [31] and fertilizer formulation $[25,28,31,38]$. Among the yam species, D. alata is a 
TABLE 5: Yield declines under native and nonnative soil fertility.

\begin{tabular}{lccc}
\hline Soil fertility type & Year 1 & Year 2 & Year 3 \\
\hline Native fertility & & & \\
D. rotundata 1 & 19.5 & 18.0 & 16.0 \\
D. rotundata 2 & 18.3 & 16.7 & 15.0 \\
\hline Mineral fertilizer & & & \\
D. alata & & & \\
D. cayenensis & 36.0 & 14.0 & 16.0 \\
D. rotundata, cv Efuru & 45.0 & 34.0 & 12.0 \\
D. rotundata, cv Aro & 40.0 & 25.0 & 11.0 \\
\hline Organic fertilizer & 36.0 & 20.0 & 11.0 \\
Goat manure & & & \\
Poultry manure & $24.5 \mathrm{~b}$ & $26.0 \mathrm{~b}$ & $27.5 \mathrm{c}$ \\
Oil palm bunch ash & $26.9 \mathrm{a}$ & $29.2 \mathrm{a}$ & $32.5 \mathrm{a}$ \\
Spent grain & $24.6 \mathrm{~b}$ & $27.5 \mathrm{~b}$ & $29.0 \mathrm{~b}$ \\
Oil palm bunch ash + goat manure & $22.0 \mathrm{c}$ & $23.9 \mathrm{c}$ & $25.0 \mathrm{c}$ \\
Oil palm bunch ash + poultry manure & $36.0 \mathrm{~d}$ & $37.5 \mathrm{e}$ & $40.0 \mathrm{~d}$ \\
Spent grain + goat manure & $31.0 \mathrm{~d}$ & $40.0 \mathrm{~d}$ & $42.5 \mathrm{~d}$ \\
Spent grain + poultry manure & $32.5 \mathrm{f}$ & $36.0 \mathrm{e}$ \\
\hline Da & $34.0 \mathrm{f}$ & $37.5 \mathrm{e}$ \\
\hline
\end{tabular}

Data sources: ${ }^{*}[63] ;^{*}$ [51] (significant differences by Duncan's multiple range test, $p=0.05) ;{ }^{\alpha}[27]$. The rest have no statistical test as they were extracted from whole datasets.

naturally high yielding yam species in both high and low fertility soils with or without fertilizer application [31, 71]. $D$. alata produced about 5 to 5.6 times more tuber yields than $D$. rotundata in Forest and Savannah soils of Côte d'Ivoire, respectively under nonfertilized conditions [31]. The impact of fertilizer on yam yields seems to be substantial in poorly fertile soils where $\mathrm{N}$ and $\mathrm{K}$ are limited [71]. In the case of agroecological zone, the Savannah zone had higher profitability for mineral fertilizer in yam production than the Forest zone during an assessment of land improvement techniques in southwestern Nigeria [18]. Earlier studies show that yam yields have generally responded well with mineral fertilizer application in the Forest-Savannah Transition zone of Ghana although there are inconsistencies in the yield trends with the same application rates and yam species [69]. The effects of different application rates of NPK $15: 15: 15$ fertilizer on $D$. rotundata yields were assessed in the Derived Savannah, Forest-Savannah Transition, and Forest ecological zones in two consecutive years [60]. The results revealed that at an application rate of $300 \mathrm{~kg} \mathrm{ha}^{-1}$ produced yields in the order Derived Savannah $>$ ForestSavannah Transition $>$ Forest zones. The optimum application rate was $300 \mathrm{~kg} \mathrm{ha}^{-1}$ for the Derived Savannah and Forest-Savannah Transition zones, whereas that of the Forest zone was $200 \mathrm{~kg} \mathrm{ha}^{-1}$. In contrast, the effects of mineral fertilizer on the yields of $D$. alata and $D$. rotundata in the Forest and Savannah zones of Côte d'Ivoire did not produce any significant effects [31].

As a major driver of yam yields, the type of soil determines the magnitude of the effects of mineral fertilizer on yam yields. In an acidic Ultisol in Nigeria, the tuber yield of $D$. rotundata increased with NPK $15: 15: 15$ fertilizer rate of $300 \mathrm{~kg} \mathrm{ha}^{-1}$ and declined by between 34 and $40 \%$ at $400 \mathrm{~kg} \mathrm{ha}^{-1}$ [60]. In a poorly fertile soil of a Forest-Savannah Transition zone of Côte d'Ivoire. Hgaza et al. [25] found that the fresh tuber yield of $D$. alata of was significantly increased by the application of Ca-fortified NPK fertilizer for two consecutive years compared to nonfertilized soil. This occurred with an increasing trend of $21 \%$ both years. Furthermore, the application of half of the recommended NPK fertilizer rate with and without the incorporation of legume residues improved the yields of $D$. rotundata in an Alfisol in southwestern Nigeria compared to the full recommended rate [28]. Observably, yam yield response to mineral fertilizer tends to decline with time from the first year of cultivation (Table 5 ). This has been consistently reported by several researchers [27, 51, 60,63]. Finally, there is currently no universally accepted fertilizer formulation for yam. However, the most common ones encountered in the literature are NPK $15: 15: 15$ [26], NPK $30: 30: 30$ and NPK $60: 60: 60$ [62], NPK $160: 10: 180$ [25], NPK $45: 45: 60$, NPK $60: 60: 80$ [38], $30: 45: 90,60: 45: 90$, and $90: 45: 90$ [21], NPK $45: 25: 37.5$ and NPK $90: 50: 75$ [28], and NPK 240 : $11: 269$ with $\mathrm{Ca}$ and $\mathrm{S}[61]$.

3.4.2. Organic Fertilizers. The use of organic fertilizers is also not without conditions. The main factors influencing the effect of organic fertilizers on yam yield are yam species, the type and quality of organic fertilizer used, the application rate, and the sequence of application or seasons receiving the organic fertilizer [70]. In a study on the effect of different application rates of poultry manure on yam tuber yields, it was observed that the tuber yield of white yam peaked at a yield of $32 \mathrm{tha}^{-1}$ with a poultry manure application rate of $20 \mathrm{tha}^{-1}$, whereas yellow yam peaked at $29 \mathrm{tha}^{-1}$ with poultry manure application rate of $30 \mathrm{tha}^{-1}$ [52]. This increase amounted to $73 \%$ and $91 \%$ for white yam in the first and second years, whereas that of yellow yam was $27 \%$ and $42 \%$ in both years, showing an increasing trend with the application of poultry manure in both cases [52]. Further, a study involving animal and plant-based manures and their mixtures revealed that the sole and mixed applications of the organic fertilizers increased the tuber yields of $D$. rotundata cv Gambari [51]. The mixed organic fertilizers gave significantly higher tuber yields than their sole applications. Among the mixtures, oil palm bunch ash + poultry manure produced the highest tuber yields compared to oil palm bunch ash + goat manure, spent grain + poultry manure, and spent grain + goat manure mixtures. The yield produced by the organic fertilizers was higher than to those of mineral fertilizers [51]. Further, cocoa pod ash + poultry manure consistently gave the highest yield of $D$. rotundata $\mathrm{cv}$ Gambari, which increased by about $7.7 \%$ up to the third year of cultivation compared to sole poultry manure and NPK $15: 15: 15$ [27]. With the same rate of application, cocoa pod ash + poultry manure increased tuber yield by $19 \%$ relative to poultry manure alone and by $36 \%$ relative to NPK $15: 15$ : 15 fertilizer, while poultry manure increased yield by $15 \%$ relative to NPK $15: 15: 15$ [27]. The combined applications of organic and mineral fertilizers have also produced encouraging results. In the Semideciduous Forest zone of Ghana, Asieku et al. [29] found the highest D. rotundata yield of $39 \mathrm{tha}^{-1}$ from the combined application of half rate (i.e., $2 t \mathrm{ha}^{-1}+150 \mathrm{~kg} \mathrm{ha}^{-1}$ ) of poultry manure and NPK 15 : 
$15: 15$ followed by the sole applications of NPK 15:15:15 $\left(300 \mathrm{~kg} \mathrm{ha}^{-1}\right)$ and poultry manure $\left(4 \mathrm{tha}^{-1}\right)$. Earlier, Akanbi et al. [72] found the largest tubers from cassava peel poultry manure compost applied to D. rotundata at $2.5 \mathrm{tha}^{-1}$ in combination with $450 \mathrm{~kg}$ NPK $15: 15: 15$. Organic fertilizer applications do not only increase yields with time but improve soil properties through successive applications $[27,51,52]$. The improved soil properties occurred as a result of increased SOM contents, reduced bulk density, and increased porosity and water holding capacity [73] which also enhance higher nutrient uptake and tuber bulking in the luxury of improved physical soil properties due to increased SOM content.

\section{Yam Yields in the Yam Belt}

Like many other crops, yam has both actual and potential yields. Typical figures of the actual yam yields are shown in Figure 3(a). Sadly, there has been a sharp decline since 2010 despite the increasing area under cultivation (Figure 3(b)). Yams are said to have high yield potentials $[1,7]$ estimated to be about 45 to $52 t \mathrm{ha}^{-1}$ under optimum fertilizer application rates and suitable growing conditions (MEDA 2011; [74]). Sadly, none of the studies consulted produced such yields except for D. alata which produced $\geq 50 t \mathrm{ha}^{-1}$ in a forest soil of Côte d'Ivoire under native soil fertility and mineral fertilizer applications [31, 61]. Generally, yam yields are influenced by climatic conditions, site and soil properties, tillage method used, year of cultivation (i.e., first and subsequent cultivation), and species $[23,24,31,50,52,61,71$, $75]$. For instance, $D$. alata is the highest yielding yam species producing at least twice the yield of other species $[31,63,71,76]$ followed by $D$. rotundata and $D$. cayenensis [52] irrespective of the ecological zone and soil fertility. This is due to the extent of nutrients extracted by the species, which translates into corresponding yields [63]. More frequently, yam yields trends have been attributed to soil fertility where the quantity of nutrients extracted has been directly related to yields. For instance, Obigbesan and Agboola [63] in a study on nutrient uptake of yam in the forest and savannah zones of Nigeria, $\mathrm{P}$ and $\mathrm{K}$ had a coefficient of determination $\left(R^{2}\right)$ of 0.98 , whereas $\mathrm{N}, \mathrm{Ca}$, and $\mathrm{Mg}$ had $R^{2}$ between 0.93 and 0.95 (Table 3). References $[31,61,71]$ also observed higher yam yields in the Humid Forest $\left(10\right.$ to $\left.54 t \mathrm{ha}^{-1}\right)$ than in the Savannah zone $(6-34 t$ ha-1), which was attributed to relatively fertile forest soils compared to less fertile savannah soils. In Ghana, the top ten yam producing districts produce yields between 15.3 and $27.4 \mathrm{tha}^{-1}$ between 2009 and 2016 accounting for 38.8 to $48.2 \%$ of the potential yield which has been pegged at $52 \mathrm{tha}^{-1}[74,77]$. These top producers are predominantly from the Savannah and Forest-Savannah Transition ecological zones.

\section{Discussions}

5.1. The Future of Yam Production. This review suggests that yam yields are influenced by climatic conditions, site and soil properties, tillage methods, year of cultivation, and species.
Among these factors, edaphic factors are cited as the most critical. Moreover, in a study on a transdisciplinary approach to sustainable yam production in the yam belt, Kiba et al. [78] discovered that land scarcity and soil fertility depletion and lower and irregular rainfall distribution were perceived as the most important constraints for yam production. This explains the reason behind the traditional shifting cultivation and fallow systems that control yam production, where yam is usually the first crop on either a freshly cleared forest or fallow land. Ultimately, soil fertility is often cited as the most important contributor of yam yield gaps in the yam belt $[25,31,61,71]$, particularly in low-input traditional system of yam cultivation [11]. Previous studies on yam production found physical soil properties such as bulk density, soil moisture, and temperature to account for $66 \%$ of yam tuber yields [50]. In a review of factors explaining yield gaps, soil fertility alone explained $69 \%$ of the yield gap records assessed, whereas soil type explained 58\% [79]. This confirms edaphic factors as the most critical drivers of yam production. Sadly, apart from land scarcity and soil degradation, the edaphic drivers are under serious threat from the effects of climate change and variability, and the only antidote is adaptation since this is beyond the control of mankind. Despite this, climate change and variability have strong interactions with soils [47].

The edaphic factors that are found in the literature, that is, tillage, soil texture and type, and fertility, and fall under the technical term soil fertility are categorized into biological, chemical, and physical. These categories can have either integrated or single effects on crop yields depending on the crop types and growth requirements. Yam seems to receive an integrated response from all the categories of soil fertility. It is observed that yam has unique tillage (i.e., ploughing + harrowing plus ridging, direct mounding, ridging, or pit) requirements to achieve low soil bulk density for yam tuber expansion as it penetrates the soil $[1,21]$. This also have a link with soil type and texture. Fundamentally, aside from ecological drivers, water availability and mineral nutrition are required for tuberization according to Posthumus [16]. Water availability depends on the physical soil properties such as texture, structure, bulk density, and porosity. Aside from texture, which is a natural soil property, the other properties are further influenced by SOM and tillage. These soil conditions are exhibited by the soils of newly cleared forest and fallow lands as well as the use of organic fertilizers $[27,51,73]$.

The chemical soil fertility is probably the next important soil fertility component as it is the seat of nutrient supply for the heavy feeding yam tubers for tuberization [16]. This is where SOM plays a major role in native soil fertility for yam as the first crop in each cropping cycle of a new crop land. It has been observed that the magnitude of nutrient extraction depends on yield and species [63]. Although $\mathrm{N}$ and $\mathrm{K}$ are the most extracted nutrients, $\mathrm{K}$ is the element most extracted by yams depending on species [63] because of its role in the accumulation of photosynthates [80]. For instance, $D$. cayenensis removed $\mathrm{K}$ almost twice that of $\mathrm{N}$, and $D$. alata removed 1.3 times, whereas $D$. rotundata removed about the same [63]. Phosphorus is the third most important element 


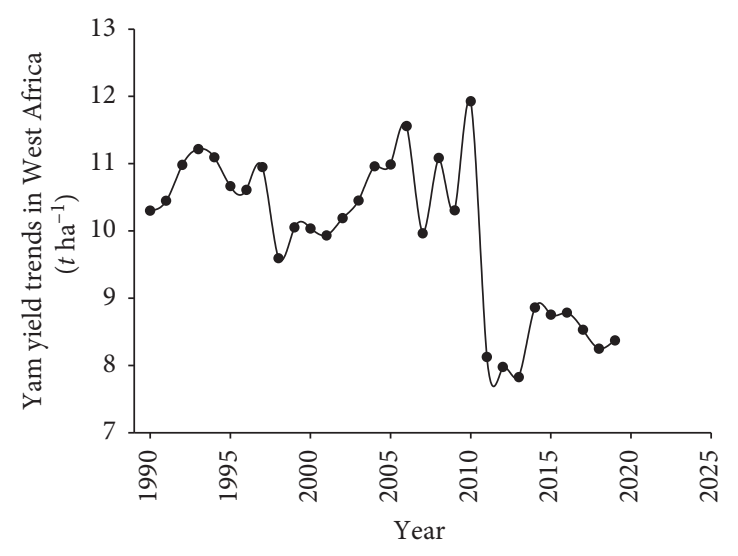

(a)

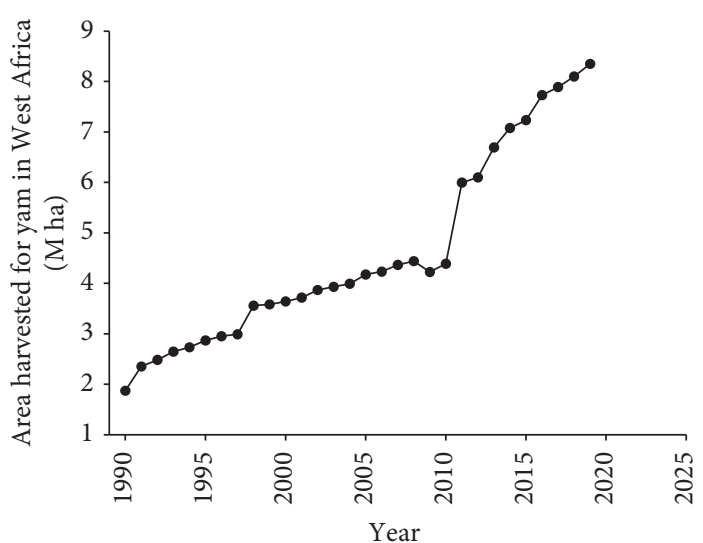

(b)

Figure 3: Yam yield trends and area under yam cultivation in West Africa from 1990 to 2019 (data source: [22]).

required for yam production followed by $\mathrm{Ca}, \mathrm{Mg}, \mathrm{Mn}, \mathrm{Zn}$, and $\mathrm{Cu}[1,31,61,63]$. Although mineral fertilizers can supply these nutrients, they do not have the additive effects that SOM has on soil properties, particularly the physical fertility that yam requires. Consequently, yam yields tend to reduce with time under native soil fertility and as mineral fertilizer application continues (Table 5). Conversely, organic fertilizers tend to increase yam tuber yields with time as the application continues in subsequent years $[27,51,52,70,73]$ because of the additive enhancement of the soil physical properties required for yam tuber bulking. Additionally, organic fertilizers slowly release nutrients into the soil. Their effect on yam yield differs with the quality of the organic fertilizer $[27,51]$ either singly or mixed (i.e., animal-animal, plant-animal, or plant-plant) as well as with the inclusion of ash or mineral fertilizers [27, 51, 72]. Despite these benefits, it is uncertain how long the effects will last, whether there is a "saturation point for application," and the roles of agroecological zone and soil type play.

Given the increasing area under yam cultivation coupled with declining yam yields (Figure 3), there is a need for urgent intervention to sustain yam production amidst growing population, urbanization, and land scarcity. Temporarily, land scarcity in yam production could be curtailed by adopting ridge tillage to increase plant density in traditional mounding from about 4000 to 10,000 plants $\mathrm{ha}^{-1}$. This could be achieved together with improved yam propagation methods. Ultimately, an intensive sedentary cultivation system should be advocated for the following reasons. (i) The tillage methods employed in yam production expose native SOM in freshly cleared land to rapid decomposition. This, coupled with the heavy feeding habits of yam then impoverishes the already poor tropical West African soils subjecting them to further degradation. (ii) Mineral fertilizer alone may not be the best antidote to the continuous yield decline because of its limited effect on physical soil properties required for optimum yam yields. (iii) There is no specific recommended mineral fertilizer application rate for different yam species, soil type, or agroecological zones considering the wide range of higher application rates (i.e., 100 to $750 \mathrm{~kg} \mathrm{ha}^{-1}$ ) used [26, 27, 72].
Besides, the application rates used are much higher than those used for other crops and could be acidifying the soil as well. Moreover, the organic fertilizer application rates of 7.5 to $40 t \mathrm{ha}^{-1}$ used are often applied without consideration for the actual nutrient contents and their ratios suited to the consistent demand for $\mathrm{N}$ and $\mathrm{K}$ by yam. Irrespective of these, nutrients in organic fertilizers are usually not in readily forms until they are released through mineralization. (iv) Finally, there is no specific fertilizer formulation for yam to achieve the optimum yields.

5.2. Prospects for Sustainable Yam Production and Soil Management. To sustain yam production in the future on limited land resources, two major proposals are presented based on existing research data and the author's experience with yam cultivation. (1) The first option is establishment of a special yam fertilizer program. Any proposed yam fertilizer formulation should be enhanced with more $\mathrm{K}$ considering that the common amounts of $\mathrm{N}$ and $\mathrm{K}$ extracted by yam are in the ratio of $1: 1$ to $1: 2$ with only about 10 to $20 \%$ of that amount for $\mathrm{P}[63,66]$. These could be fortified by minor quantities of $\mathrm{Ca}$ and $\mathrm{Mg}$ and relevant micronutrients. Afterwards, further research on the yam fertilizer formulations focusing on the $\mathrm{N}$ and $\mathrm{K}$ requirements recommended application rates for different yam species, soil types, and agroecological zones could be conducted for validation. Additionally, the research could also compare one-time and split fertilizer applications to suit different stages of yam growth and tuber bulking. Unfortunately, this option may not improve the physical properties of the soil.

Therefore, a second and more sustainable option could be to (2) adopt the "Terra Preta Model" in the long term. The long-term additive effects of organic fertilizers on yam yields and soil properties as found in the literature could be leveraged here as well as to sustain yam production. However, there is the concern for sustainability given the hot temperatures in West Africa and the lability of SOM. The questions posed here are the following. Could the Terra Preta Model be the hope for sustainable yam farming in West Africa? What is the "Terra Preta Model"? The "Terra Preta 
Model" refers to activities, processes, and inputs that lead to the formation Terra Preta soils. Terra Preta soils are anthrosols, also called Indian or Amazonian black earths, mainly Oxisols, Ultisols, and Inceptisols with an A horizon enriched with more humified organic carbon due to longterm charcoal accumulation forming more stable aggregates and a crumb soil structure [81]. According to Glaser [82], Terra Preta could be traced to a combination of organic domestic wastes of plant and animal origin mixed with ash and charcoal resulting in an enrichment of $\mathrm{N}, \mathrm{P}, \mathrm{K}, \mathrm{Ca}, \mathrm{Mg}$, etc. Consequently, Terra Preta contains about threefold SOM, N, and $\mathrm{P}$ and much more charcoal than neighboring soils [82] and is less acidic ( $\mathrm{pH} 5.1$ - 6.5) [81] and has higher CEC and base saturation, compared to neighboring soils [83]. Terra Preta is similar to a typical refuse dump soil developed over a period from the continuous dumping of organic wastes, ash, and unburnt charcoal pieces. Dump soil can develop in about three years onwards from the start of waste dumping. Practically, the adoption of the Terra Preta Model could be achieved through the integrated and continuous use of biochar, ash, manures, and compost for yam production. Although the wide interest in biochar application was based on the unique impact of charcoal on the properties of Terra Preta soils, there are no records of intentional adoption of the Terra Preta Model. However, some studies have mimicked a "temporary" Terra Preta Model $[27,51,84]$. For instance, at least $50 \%$ higher yam yields (Table 4) were obtained from the combined application of manure and ashes [27]. Moreover, cocoyam tuber yields were obtained along with decreased bulk density, increased porosity and soil moisture retention, increased soil $\mathrm{pH}, \mathrm{OC}$, $\mathrm{N}, \mathrm{P}, \mathrm{K}, \mathrm{Ca}$, and $\mathrm{Mg}$ contents all with the application of biochar and poultry manure [84]. These results were often obtained after repeated applications in subsequent years of cultivation. The bulk density, an important determinant of yam, yields, decreased by between 15 and $47 \%$ within two years of application $[51,84]$. These effects are similar to the properties of Terra Preta soils and create the required edaphic drivers outlined in the literature for enhanced yam yields. This review revealed that the Terra Preta Model produces synergy in tuber yields and soil fertility, which could eventually curb the soil mining potential in yam production. Additionally, the Terra Preta Model is considered to have a long-term C storage [85]. Sadly, there is currently no standard recommended application rate of biochar, compost, and manure for optimum yam yields and target residual soil fertility for subsequent growing seasons. This, therefore, calls for further research on these aspects.

\section{Conclusions}

This review showed that the major ecological drivers of yam production are the specific agroecology, cultural practices, and the impacts of climate change and variability. These collectively have direct and indirect effects on photosynthesis and the storage of photosynthates in yam tubers. They control the amount of photosynthates available for storage in tubers. This begins from the emergence of yam shoots from the sett to tuber initiation and is strongly influenced by photoperiod, which is further linked to the season and planting dates. The edaphic drivers are tillage, soil texture and type, and soil fertility. The specific edaphic factors sum up to one thing; soil fertility encompasses the biological, chemical, and physical fertility related to nutrient supply and loose soil conditions for easy yam tuber bulking. It was observed that soil fertility is a major constraint in yam production because yam degrades soil by extracting high amounts of nutrients. This leads to declining yam yields both under native soil fertility and mineral fertilizer applications. Organic fertilizers rather increase yield under repeated applications and improve soil conditions. Within the past decade, yam yields have declined sharply amidst increasing areas under cultivation. Given the nonsedentary system of yam production, future yam production is likely saddled with land scarcity and degraded soils. Although artificial fallows have been used in some areas to restore soil fertility, it is not sustainable owing to population increase. Consequently, two proposals are presented: (1) the establishment of a special fertilizer program to develop specific yam fertilizer formulations, particularly aiming at more $\mathrm{K}$, considering that the common amounts of $\mathrm{N}$ and $\mathrm{K}$ extracted by yam and (2) adoption of the "Terra Preta Model" in the long term where organic fertilizers and biochar are strategically achieved through repeated applications over a period.

\section{Data Availability}

All data generated or analyzed during this study are from published articles.

\section{Conflicts of Interest}

The authors declare that they have no conflicts of interest.

\section{References}

[1] V. Lebot, Tropical Root and Tuber Crops, CABI, Wallingford, UK, 2009.

[2] FAOSTAT, Yam production in west Africa, food and agriculture organization http://www.fao.org/faostat/en/\#data, 2021.

[3] N. G. Maroya, R. Asiedu, L. P. Kumar, A. Lopez-Montes, J. Orchard, and F. Ndiame, YIIFSWA Working Paper Series No. 1. Yam Improvement for Income and Food Security in West Africa, p. 18, International Institute of Tropical Agriculture, Ibadan, Nigeria, 2014.

[4] D. B. Mignouna, A. A. Akinola, I. Suleman, F. Nweke, and T. Abdoulaye, YIIFSWA Working Paper Series No. 3. Yam Improvement for Income and Food Security in West Africa, p. 46, International Institute of Tropical Agriculture, Ibadan, Nigeria, 2014.

[5] GEPA, Ghana export promotion authority: potential markets -yam https://www.gepaghana.org/import/ghana-product/ yams-from-ghana/, 2019.

[6] CIA, The central intelligence agency of the US: the world factbook https://www.cia.gov/index.html, 2020.

[7] R. Asiedu and A. Sartie, "Crops that feed the world 1. Yams," Food Security, vol. 2, no. 4, pp. 305-315, 2010. 
[8] O. B. Izekor and M. I. Olumese, "Determinants of yam production and profitability in Edo State, Nigeria," African Journal of Agricultural Research, vol. 6, pp. 205-210, 2010.

[9] O. A. Eyitayo, T. O. Anthony, and I. Theresas, "Economics of seed yam production using minisett technique. Field actions science report, vol. 4, oyo state, Nigeria," Field Actions Science Reports, vol. 4, 2010.

[10] F. O. Idumah, P. T. Owombo, and U. B. Ighodaro, "Economics of yam production under agroforestry system in sapoba forest area, edo state, Nigeria," International Journal of Agriculture Environment, vol. 4, pp. 440-445, 2014.

[11] A. M. Kouakou, G. F. Yao, K. E. B Dibi et al., "Yam cropping system in Côte d'Ivoire: current practices and constraints," European Scientific Journal, vol. 15, pp. 278-300, 2019.

[12] D. B. Mignouna, T. Abdoulaye, A. A. Akinola, A. Alene, and F. Nweke, "Factors influencing the use of selected inputs in yam production in Nigeria and Ghana," Journal of Agriculture and Rural Development in the Tropics, vol. 116, pp. 131-142, 2015.

[13] A. Wumbei, J. K. A. Bawa, M. A. Akudugu, and P. Spanoghe, "Absence of effects of herbicides use on yam rots: a case study in Wulensi, Ghana," Agriculture, vol. 9, p. 95, 2019.

[14] A. Wumbei, L. Goeteyn, E. Lopez, M. Houbraken, and P. Spanoghe, "Glyphosate in yam from Ghana," Food Additives \& Contaminants: Part B, vol. 12, pp. 231-235, 2019b.

[15] L. M. Srivastava, Planta growth and development: hormones and environment, Academic Press, Cambridge, Massachusetts, USA, pp. 473-520, 2002.

[16] A. C. Posthumus, "Environmental factors affecting tuberization," in Proceedings of the 3rd Symp. Int. Soc. Trop. Root Crops, pp. 51-59, Ibadan, Nigeria, July 1973.

[17] H. Yasuoka, "Concentrated distribution of wild yam patches: historical ecology and the subsistence of African rainforest hunter-gatherers," Human Ecology, vol. 37, pp. 577-587, 2009.

[18] A. S. Bamire and B. J. Amujoyegbe, "Economic analysis of land improvement techniques in smallholder yam-based production systems in the agro-ecological zones of southwestern Nigeria," Journal of Human Ecology, vol. 18, no. 1, pp. 1-12, 2005.

[19] F. Nweke, R. Aidoo, and B. Okoye, Yam Consumption Patterns in West Africa, Final Report for Bill and Melinda Gates Foundation (BMGF), 2013.

[20] E. O. Danquah, S. A. Ennin, J. N. L. Lamptey, and P. P. Acheampong, "Staking options for sustainable yam production in Ghana," Sustainable Agriculture Research, vol. 4, no. 1, pp. 106-113, 2015.

[21] S. A. Ennin, E. Otoo, and F. M. Tetteh, "Ridging, a mechanized alternative to mounding for yam and cassava production," West African Journal of Applied Ecology, vol. 15, 2009.

[22] FAO, FAO Forest Resource Assessment http://www.fao.org/ forestry/country/19971/en/ben/, 2000.

[23] R. Maliki and M. Toukourou, "Productivity of yam-based systems with herbaceous legumes and short fallows in the Guinea-Sudan transition zone of Benin," Nutrient Cycling in Agroecosystems, vol. 92, pp. 9-19, 2011.

[24] R. Maliki, B. Sinsin, A. Floquet, D. Cornet, E. Malezieux, and P. Vernier, "Dry matter production, nutrient cycled and removed, and soil fertility changes in yam-based cropping systems with herbaceous legumes in the Guinea-Sudan zone of Benin," Scientifica, vol. 2016, Article ID 5212563, 12 pages, 2016.

[25] V. K. Hgaza, L. N. Diby, A. Assa, and S. Ake, "How fertilization affects yam (Dioscorea alata L.) growth and tuber yield across the years," African Journal of Plant Science, vol. 4, pp. 53-60, 2010.

[26] K. E. Law-Ogbomo and C. O. Emokaro, "Economic analysis of the effect of fertilizer application on the performance of white Guinea yam in different ecological zones of Edo State, Nigeria," World Journal of Agricultural Sciences, vol. 5, pp. 121-125, 2009.

[27] T. M. Agbede and A. O. Adekiya, "Effects of sole and integrated application of cocoa pod ash and poultry manure on soil properties and leaf nutrient composition and performance of white yam," International Journal of Biological, Biomolecular, Agricultural, Food and Biotechnological Engineering, vol. 10, pp. 281-288, 2016.

[28] G. O. Kolawole, "Effects of leguminous plant residues and NPK fertilizer application on the performance of yam (Dioscorea rotundata 'c.v.' ewuru) in south-western Nigeria," Archives of Agronomy and Soil Science, vol. 59, pp. 423-434, 2013.

[29] Y. Asieku, E. Otoo, and E. Asare, "Yield and storage characteristics of white yam (Dioscorea rotundata Poir) as influenced by fertilizer application and time of harvesting in forest zone of Ghana," Journal of Scientific Research and Reports, vol. 8, no. 6, pp. 1-7, 2015.

[30] A. Zannou, P. Struik, P. Richards, and J. Zoundjihékpon, "Yam (Dioscorea spp.) responses to the environmental variability in the Guinea Sudan zone of Benin," African Journal of Agricultural Research, vol. 10, pp. 4913-4925, 2015.

[31] L. N. Diby, V. K. Hgaza, T. B. Tié et al., "How does soil fertility affect yam growth?” Acta Agriculturae Scandinavica, Section B - Soil \& Plant Science, vol. 61, pp. 448-457, 2011.

[32] J. Marcos, A. Lacointe, R. Tournebize, R. Bonhomme, and J. Sierra, "Water yam (Dioscorea alata L.) development as affected by photoperiod and temperature: experiment and modeling," Field Crop Research, vol. 111, pp. 262-268, 2009.

[33] M. V. Melteras, V. Lebot, C. J. Asher, and J. N. O’Sullivan, "Crop development and root distribution in lesser yam (Dioscorea esculenta): implications for fertilization," Australian Journal of Experimental Agriculture, vol. 44, pp. 209221, 2008.

[34] N. Chukwuone, Analysis of Impact of Climate Change on Growth and Yield of Yam and Cassava and Adaptation Strategies by Farmers in Southern Nigeria, African Growth and Development Policy Modelling Consortium (AGRODEP) Working Paper 0012, 2015.

[35] F. O. Olasantan, "Effect of time of mulching on soil temperature and moisture regime and emergence, growth and yield of white yam in western Nigeria," Soil \& Tillage Research, vol. 50, pp. 215-221, 1999.

[36] P. A. O. Odjugo, "The effect of tillage systems and mulching on soil microclimate, growth and yield of yellow yam (Dioscorea cayenensis) in Midwestern Nigeria," African Journal of Biotechnology, vol. 7, pp. 4500-4507, 2008.

[37] T. M. Agbede, A. O. Adekiya, and J. S. Ogeh, "Response of soil properties and yam yield toChromolaena odorata(Asteraceae) andTithonia diversifolia(Asteraceae) mulches," Archives of Agronomy and Soil Science, vol. 60, no. 2, pp. 209-224, 2014.

[38] S. A. Ennin, R. N. Issaka, P. P. Acheampong, M. Numafo, and E. O. Danquah, "Mechanization, fertilization and staking for environmentally sound yam production," African Journal of Agricultural Research, vol. 9, pp. 2222-2230, 2014.

[39] E. Otoo, S. A. Ennin, and E. O. Ekpe, "Yam production in Ghana: to stake or not to stake - a plant breeding perspective," in Proceedings of the 13th ISTRC Symposium, pp. 51-55, 2007. 
[40] N. Verter and V. Bečvařova, "An analysis of yam production in Nigeria," Acta Universitatis Agriculturae et Silviculturae Mendelianae, vol. 63, pp. 659-665, 2015.

[41] J. Cook, C. L. Anderson, and S. Curran, Gender and Cropping: Yam in Sub-saharan Africa, Evans Policy Analysis and Research (EPAR) Evans School of Public Affairs, prepared for the Science and Technology Team of the Bill \& Melinda Gates Foundation, 2009.

[42] B. Sarr, "Present and future climate change in the semi-arid region of West Africa: a crucial input for practical adaptation in agriculture," Atmospheric Science Letters, vol. 13, pp. 108$112,2012$.

[43] J. H. Kotir, "Climate change and variability in Sub-Saharan Africa: a review of current and future trends and impacts on agriculture and food security," Environment, Development and Sustainability, vol. 13, pp. 587-605, 2011.

[44] M. B. Sylla, P. M. Nikiema, P. Gibba et al., Adaptation to Climate Change and Variability in Rural West Africa, Springer International Publishing Switzerland, Switzerland, pp. 25-40, 2016.

[45] P. Roudier, B. Sultan, P. Quirion, and A. Berg, "The impact of future climate change on West African crop yields: what does the recent literature say?" Global Environmental Change, vol. 21, pp. 1073-1083, 2011.

[46] S. S. Jagtap and A. K. Chan, "Agrometeorological aspects of agriculture in the sub-humid and humid zones of Africa and Asia," Agricultural and Forest Meteorology, vol. 103, pp. 5972, 2000.

[47] A. K. Srivastava, T. Gaiser, H. Paeth, and F. Ewert, "The impact of climate change on yam (Dioscorea alata) yield in the savanna zone of West Africa," Agriculture, Ecosystems \& Environment, vol. 153, pp. 57-64, 2012.

[48] T. Agbede, "Effect of tillage on soil properties and yam yield on an Alfisol in southwestern Nigeria," Soil and Tillage Research, vol. 86, no. 1, pp. 1-8, 2006.

[49] B. T. Kang and J. E. Wilson, "Effect of mound size and fertilizer on white Guinea yam (Dioscorea rotondata) in southern Nigeria," Plant and Soil, vol. 61, pp. 319-327, 1981.

[50] T. M. Agbede and A. O. Adekiya, "Soil properties and yam yield under different tillage systems in a tropical Alfisol," Archives of Agronomy and Soil Science, vol. 59, no. 4, pp. 505-519, 2013.

[51] T. M. Agbede, A. O. Adekiya, and J. S. Ogeh, "Effects of organic fertilizers on yam productivity and some soil properties of a nutrient-depleted tropical Alfisol," Archives of Agronomy and Soil Science, vol. 59, no. 6, pp. 803-822, 2013.

[52] T. M. Agbede and A. O. Adekiya, "Effects of poultry manure on soil fertility, growth and yield of white yam and yellow yam," University of Khartoum Journal of Agricultural Sciences, vol. 20, pp. 286-303, 2012.

[53] D. A. Okpara, A. A. Udo, M. Iroegbu, and J. G. Ikeogu, "Effect of fallow species and fallow duration on soil fertility, biomass and white yam (Dioscorea rotundata Poir) production," Biological Agriculture \& Horticulture, vol. 27, pp. 165-177, 2011.

[54] K. S. Amanor and O. Pabi, "Space, time, rhetoric and agricultural change in the transition zone of Ghana," Human Ecology, vol. 35, no. 1, pp. 51-67, 2007.

[55] E. O. Danquah, S. A. Ennin, F. Frimpong, M. Akom, and P. P. Acheampong, "Improved agronomic practices for sustainable yam production: the on farm experience," Agricultural and Food Science Journal of Ghana, vol. 11, pp. 904-908, 2018.

[56] B. Aighewi, N. Maroya, P. L. Kumar et al., "Seed yam production using high-quality minitubers derived from plants established with vine cuttings," Agronomy, vol. 11, no. 5, p. $978,2021$.

[57] K. E. Law-Ogbomo and A. U. Osaigbovo, "Effects of plant density and NPK application on the growth and yield of white Guinea yam (Dioscorea rotundata Poir) in a forest zone of Nigeria," African Journal of Food, Agriculture, Nutrition and Development, vol. 14, pp. 2204-2217, 2014.

[58] K. S. John, "Soil fertility management strategies in edible yams and aroids: a review," Journal of Root Crops, vol. 37, pp. 3-18, 2011.

[59] H. Shiwachi, C. C. Okonkwo, and R. Asiedu, "Nutrient deficiency symptoms in yams (Dioscorea spp.)," International Journal of Tropical Insect Science, vol. 44, pp. 155-162, 2004.

[60] K. E. Law-Ogbomo and S. U. Remison, "Yield and distribution/uptake of nutrients of Dioscorea rotundata influenced by NPK fertilizer application," Notulae Botanicae Horti Agrobotanici Cluj-Napoca, vol. 37, pp. 165-170, 2009.

[61] L. N. Diby, V. K. Hgaza, T. B Tie et al., "Productivity of yams (Dioscorea spp.) as affected by soil fertility," Journal of Animal and Plant Sciences, vol. 5, pp. 494-506, 2009.

[62] M. Akom, C. Oti-Boateng, E. Otoo, and E. Dawoe, "Effect of biochar and inorganic fertilizer in yam (Dioscorea rotundata Poir) production in a Forest agroecological zone," Journal of Agricultural Science, vol. 7, no. 3, pp. 211-222, 2015.

[63] G. O. Obigbesan and A. A. Agboola, "Uptake and distribution of nutrients by yams (Dioscorea spp.) in western Nigeria," Experimental Agriculture, vol. 14, pp. 349-355, 1978.

[64] L. N. Diby, V. K. Hgaza, T. B. Tié, R. Carsky, O. Girardin, and A. Assa, "Mineral nutrients uptake and partitioning in Disocorea alata and Dioscora rotundata," Journal of Applied Biosciences, vol. 38, pp. 2531-2539, 2011c.

[65] H. Kikuno, H. Shiwachi, Y. Hasegawa, J. Ohata, and R. Asiedu, "Effects of nitrogen application on off-season yam cropping after lowland rice in a derived savanna zone in Nigeria," Tropical Agriculture and Development, vol. 59, pp. 146-153, 2015.

[66] S. Kabeerathumma, B. M. Kumar, and P. G. Nair, Nutrient Uptake and Their Utilization by Yams, Aroids and Coleus Technical Bulletin Series-10, Central Tuber Crops Research Institute, Sreekariyam, Thiruvananthapuram, India, 1987.

[67] M. Jemo, O. J. Jayeoba, T. Alabi, and A. L. Mont, "Geostatistical mapping of soil fertility constraints for yam based cropping systems of North-central and Southeast Nigeria," Geoderma Regional, vol. 2, no. 3, pp. 102-109, 2014.

[68] S.-P. A. Y. Kassi, A. W. Koné, J. E. Tondoh, and B. Y. Koffi, "Chromoleana odorata fallow-cropping cycles maintain soil carbon stocks and yam yields 40 years after conversion of native- to farmland, implications for forest conservation," Agriculture, Ecosystems \& Environment, vol. 247, pp. 298-307, 2017.

[69] FAO, Fertilizer use by crop in Ghana. Land and plant nutrition management service land and water development division food and agriculture organization of the united nations http://www.fao.org/docrep/008/a0013e/a0013e09. htm, 2005.

[70] S. C. Eze and G. C. Orkwor, "Studies on effects of mineral fertilizer, organic manure and cultivar on the yield and storability of yam (Dioscorea rotundata Poir)," African Journal of Food, Agriculture, Nutrition and Development, vol. 10, no. 6, 2010.

[71] L. N. G. Diby, B. T. Tie, O. Girardin, R. Sangakkara, and E. Frossard, "Growth and nutrient use efficiencies of yams (dioscoreaspp.) grown in two contrasting soils of West 
Africa," International Journal of Agronomy, vol. 2011, Article ID 175958, 8 pages, 2011.

[72] W. B. Akanbi, O. A. Olaniran, and A. B. Olaniyan, "Effects of integrated use of organic and inorganic nutrient sources on growth and tuber characteristics of white yam (Dioscorea rotundata) cv ehuru," African Crop Science conference proceedings, vol. 8, pp. 359-353, 2007.

[73] G. Suja and J. Sreekumar, "Implications of organic management on yield, tuber quality and soil health in yams in the humid tropics," International Journal of Plant Production, vol. 8, pp. 291-310, 2014.

[74] MOFA, Agriculture in Ghana: Facts and Figures 2016. Statistics, Research and Information Directorate, Ministry of Food and Agriculture (MoFA), Accra, Ghana, 2017.

[75] R. J. Carsky, R. Asiedu, and D. Cornet, "Review of soil fertility management for yam-based systems in West Africa," African journal of root and tuber crops, vol. 8, pp. 1-17, 2010.

[76] K. V. Hgaza, A. Oberson, I. D. Kiba, L. N'Guessan, S. A. Diby, and E. Frossard, "The nitrogen nutrition of yam (Dioscorea spp)," Journal of Plant Nutrition, vol. 43, pp. 64-78, 2020.

[77] MOFA, Statistics, Research and Information Directorate, Ministry of Food and Agriculture (MoFA), Accra, Ghana, 2016.

[78] D. I. Kiba, V. K. Hgaza, B Aighewi et al., "A transdisciplinary approach for the development of sustainable yam (Dioscorea $s p$.) production in west Africa," Sustainability, vol. 12, p. 4016, 2020.

[79] E. Beza, J. V. Silva, L. Kooistra, and P. Reidsma, "Review of yield gap explaining factors and opportunities for alternative data collection approaches," European Journal of Agronomy, vol. 82, pp. 206-222, 2017.

[80] S. Wang, H. Li, Q. Liu, and Y. Shi, "Effect of potassium application on root grow and yield of sweet potato and its physiological mechanism," Acta Agronomica Sinica, vol. 43, pp. 1057-1066, 2017.

[81] H. N. Lima, C. E. R. Schaefer, and J. W. V. Mello, "Pedogenesis and pre-Colombian land use of "Terra preta Anthrosols" ("Indian black earth") of western amazonia," Geoderma, vol. 110, pp. 1-17, 2002.

[82] B. Glaser, "Prehistorically modified soils of Central Amazonia: a model for sustainable agriculture in the 21st century?" Philosophical Transactions of the Royal Society B, vol. 362, pp. 187-196, 2007.

[83] E. H. Novotny, M. H. Hayes, B. E Madari et al., "Lessons from the Terra Preta de Índios of the Amazon region for the utilisation of charcoal for soil amendment," Journal of the Brazilian Chemical Society, vol. 20, pp. 1003-1010, 2009.

[84] T. M. Agbede, A. O. Adekiya, A. S. Odoja, L. N. Bayode, P. O. Omotehinse, and I. Adepehin, "Effects of biochar and poultry manure on soil properties, growth, quality, and yield of cocoyam (Xanthosoma sagittifolium Schott) in degraded tropical sandy soil," Experimental Agriculture, vol. 56, no. 4, pp. 528-543, 2020.

[85] B. Glaser and J. J. Birk, "State of the scientific knowledge on properties and genesis of Anthropogenic Dark Earths in Central Amazonia (terra preta de Índio)," Geochimica et Cosmochimica Acta, vol. 82, pp. 39-51, 2012. 